\title{
COMPARATIVE STUDY ON EFFECTS OF DIGESTATE AND CATTLE SLURRY APPLICATION ON N DYNAMICS IN FERTILIZED SOIL
}

\author{
Agnieszka Wysocka-Czubaszek, Robert Czubaszek, Slawomir Roj-Rojewski, Piotr Banaszuk \\ Bialystok University of Technology, Poland \\ a.wysocka@pb.edu.pl,r.czubaszek@pb.edu.pl,s.roj@pb.edu.pl, p.banaszuk@pb.edu.pl
}

\begin{abstract}
Anaerobic digestion of energy crops and wastes of different origin are widely recognized as a climateneutral source of energy, while digestate became valuable fertilizer substituting animal manure. To compare the effect of soil fertilization with digestates and cattle slurry on nitrogen dynamics we ran an incubation experiment. The loamy sand soil was amended with: (1) anaerobically digested maize silage with chicken droppings and potato pulp (MSD); (2) anaerobically digested common reed silage (CRD) and (3) raw cattle slurry (CS). All fertilizers supplied $\mathrm{NH}_{4}-\mathrm{N}$ to the soil. However, the addition of CS resulted in the highest $\mathrm{NH}_{4}-\mathrm{N}$ content in the soil. The $\mathrm{NH}_{4}-\mathrm{N}$ dynamics showed a similar overall pattern with some differences in the first week of incubation. Soils fertilized with $\mathrm{CR}$ and MSD showed a rapid transformation of $\mathrm{NH}_{4}-\mathrm{N}$ resulting in its decline in the first two weeks after digestate application with the further slower decrease, while in soil fertilized with CS this process was more gradual. However, in all cases after 42 days, the $\mathrm{NH}_{4}-\mathrm{N}$ content decreased to values close to zero, which remained until the end of incubation on day 56. Contrasting to $\mathrm{NH}_{4}-\mathrm{N}$, the content of $\mathrm{NO}_{3}-\mathrm{N}$ was initially low and similar in all treated soils and control. The $\mathrm{NO}_{3}-\mathrm{N}$ concentration in the samples treated with $\mathrm{CR}$ and CS rose rapidly from day 2 to day 28. In the soil fertilized with $\mathrm{MSD}$, the $\mathrm{NO}_{3}-\mathrm{N}$ content increased gradually and reached its maximum on the $42^{\text {nd }}$ day of the experiment. Addition of different organic fertilizers to the soil triggered a range of processes including nitrification, immobilization, and emission, however, the most pronounced process was nitrification of the applied $\mathrm{NH}_{4}-\mathrm{N}$. The pattern of inorganic-N transformation suggests that digestate can be used successfully as organic fertilizer but fast nitrification may lead to enhanced loss of $\mathrm{NO}_{3}-\mathrm{N}$ by leaching. Therefore, application of digestate should follow the same rules as traditional liquid organic fertilizers.
\end{abstract}

Keywords: digestate, nitrogen dynamics, cattle slurry.

\section{Introduction}

The greenhouse gasses (GHG) emissions, the depletion of limited natural resources such as fossil fuels or nutrient resources, e.g., phosphorus drew the humankind attention to renewable energy production and circular economy, which essential idea is the reuse of waste as a new resource. The anaerobic digestion (AD) of farm and agroindustrial residues, as well as domestic organic wastes and energy crops, becomes one of the main sources of GHG-free energy and valuable fertilizer at the same time. The digestate is the AD process by-product characterized by high level of plant available ammonium-nitrogen [1], the total amount of phosphorus and potassium at a level similar to this in the substrate used for biogas production [2] and no serious ecotoxicological effect on plants and soil biota [3]. While using digestate from $\mathrm{AD}$ processing of wastes presents mostly advantages, the biogas slurry formed in the $\mathrm{AD}$ of energy crops is more controversial, because dedicated crops demand high amounts of fossil fuels and nutrients, they occupy land originally used for food and forage production and may have an adverse effect on soil quality [4]. Therefore, new substrates such as biomass from the landscape management in nature reserves, conservation areas [5;6] and buffer strips [7] are considered as a substitution for energy crops. Especially common reed is a species of great importance because of high biomass production and aggressive expansion in wetland ecosystems, which force mowing as a management activity aimed towards the preservation of species composition in protected wetlands [8].

The digestate composition and stability may vary greatly depending on the substrates used in the $\mathrm{AD}$ process [9] and consequently the growing trend of soil fertilization with biogas slurry of unknown chemical and biological properties is observed [2]. The proper use of digestate may diminish its potential negative environmental impact, especially in case of nitrogen, which may be leached and pollute water or may be volatilized to the atmosphere. The dynamics of nitrogen in soil after digestate application has been well recognized in case of commercially produced biogas slurries from energy crops, agricultural and agroindustrial wastes $[1 ; 9]$. The $\mathrm{N}$ dynamics and release are mainly influenced by the digestate properties such as the mineral $\mathrm{N}$ content [1]. The $\mathrm{N}$ nitrification rate is quite high and similar to this obtained in soils amended with raw animal slurry [10]. Less is known about $\mathrm{N}$ dynamics 
in soils fertilized with digestate produced from substrates such as wetland plants. Also, comparative studies between digestates and undigested slurries are scarce.

The aim of this study was, therefore, comparative investigation of $\mathrm{N}$ dynamics in soil fertilized with (1) digestate from commercial biogas plant fed with maize silage, chicken droppings and potato pulp; (2) digestate from biomethane potential test of common reed silage; and (3) raw cattle slurry.

\section{Materials and methods}

\section{The characteristics of soil and organic fertilizers}

A loamy sand soil (83\% of sand, $16 \%$ silt and $1 \%$ clay) was used in the incubation experiment. The soil was collected from 0-0.2 m depth (plough horizon) of the arable field at the organic farm located in the vicinity of Białystok $\left(53^{\circ} 17^{\prime} \mathrm{N}, 23^{\circ} 11^{\prime} \mathrm{E}, 147 \mathrm{~m}\right.$ a.s.l.). The soil was air-dried and sieved through $2 \mathrm{~mm}$ mesh prior to incubation. The main soil properties were as follows: $\mathrm{pH}_{\mathrm{KCl}} 4.75 \pm 0.12$, nitrate nitrogen $\left(\mathrm{NO}_{3}-\mathrm{N}\right) 2.85 \pm 0.23 \mathrm{mg} \cdot \mathrm{kg}^{-1}$, ammonium nitrogen $\left(\mathrm{NH}_{4}-\mathrm{N}\right) 27.98 \pm 0.98 \mathrm{mg} \cdot \mathrm{kg}^{-1}$, organic carbon $15.46 \pm 1.08 \mathrm{~g} \cdot \mathrm{kg}^{-1}$, total nitrogen $(\mathrm{TN}) 0.90 \pm 0.02 \mathrm{~g} \cdot \mathrm{kg}^{-1}$. Three organic fertilizers were used in the experiment: (1) digestate from mesophilic biogas plant, where maize silage $(80 \%)$, chicken droppings $(10 \%)$ and potato pulp $(10 \%)$ were co-digested; (2) digestate from biomethane potential test of common reed (Phragmites australis (Cav.) Trin. ex Steud.) silage; (3) cattle slurry obtained from a dairy farm. The chemical characteristics of the organic material are shown in Table 1 .

\section{The incubation experiment}

The aerobic incubation experiment was carried out in darkness at temperature $25 \pm 1{ }^{\circ} \mathrm{C}$ for 56 days. Prior incubation the soil moisture was adjusted to $60 \%$ of water holding capacity (WHC) and maintained during the experiment with distilled water. Periodically the samples were weighted and WHC was adjusted by adding distilled water drop by drop. The organic materials were added to the soil at the rate equivalent to field application of $170 \mathrm{~kg} \cdot \mathrm{N} \cdot \mathrm{ha}{ }^{-1}$, which is the recommended annual rate of $\mathrm{N}$ applied in organic fertilizers [11]. The exact amount of organic material added to $77 \mathrm{~g}$ of soil with $60 \%$ WHC was calculated assuming the cultivation depth of $0.2 \mathrm{~m}$. The bulk density of soil was $1.51 \mathrm{~g} \cdot \mathrm{cm}^{-3}$. The soil homogeneously mixed with fertilizers was placed in plastic vessels $(100 \mathrm{ml}$ capacity) without drainage holes and covered with Parafilm, which is highly permeable to gases but retains moisture. The soil without addition of organic material was used as a control. Each treatment and control were run in triplicate. The evolution of $\mathrm{pH}$, electrical conductivity (EC) and inorganic forms of nitrogen $\left(\mathrm{NH}_{4}-\mathrm{N}\right.$ and $\mathrm{NO}_{3}-\mathrm{N}$ ) were followed periodically (on $0,2,7,14,28,42$ and 56 days).

\section{Analytical methods}

Soil particle-size distribution was determined according to the Bouyoucos method in modification by Casagrande and Prószyński. Bulk density was determined in undisturbed soil samples in a steal cylinder with volume of $100 \mathrm{~cm}^{3}$. The soil moisture was determined by drying $10 \mathrm{~g}$ of a sample in $105 \pm 2{ }^{\circ} \mathrm{C}$ until constant weight. The soil electrical conductivity (EC) was determined in $1: 2.5$ (w/v as $\mathrm{g} / \mathrm{ml})$ soil distilled water suspension and $\mathrm{pH}_{\mathrm{KCl}}$ were measured in $1: 2.5(\mathrm{w} / \mathrm{v}$ as $\mathrm{g} / \mathrm{ml})$ soil $0.1 \mathrm{M} \mathrm{KCl}$ suspension with a pH meter HQD 40 (Hach, USA). The $\mathrm{NH}_{4}-\mathrm{N}$ and $\mathrm{NO}_{3}-\mathrm{N}$ were extracted on $10 \mathrm{~g}$

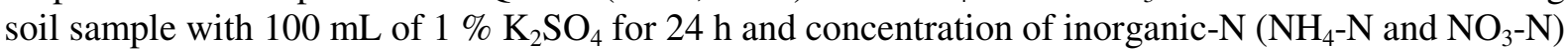
was measured by the spectrophotometer UV-1800 (Shimadzu, Japan) in filtrates. Organic carbon was determined in the TOC-L analyser with SSM-5000A Solid Sample Combustion Unit (Shimadzu, Japan). Total nitrogen (TN) was determined by the Kjeldahl method in the Vapodest 50s analyzer (Gerhardt, Germany).

In organic materials total solids (TS) and volatile solids (VS) were measured according to standard methods [12]. All fresh organic materials were analyzed for $\mathrm{pH}$ and EC using the HQD 40 meter (Hach, USA) and for total Kjeldahl nitrogen (TKN) by the Kjeldahl method in the Vapodest 50s analyzer (Gerhardt, Germany). Total organic carbon (TOC) was determined with the TOC-L analyser with SSM-5000A Solid Sample Combustion Unit (Shimadzu, Japan). The analyses of soil and organic materials were run in triplicate. 


\section{Statistical methods}

The results were checked for normal distribution with the Shapiro-Wilk test and for homogeneity of variance with the Levene test. Then the one-way analysis of variance (ANOVA) was used to determine the effect of organic amendment type on the main properties and the differences between means were further analysed with the HSD Tukey test. The ANOVA with the Welch test was performed separately for the incubation time and type of organic fertilizers because of inhomogeneity of the results obtained from the soil chemical analyses. All data were analysed using Statistica 12 software.

\section{Results and discussion}

The amendment type had significant influence on the total solids $(p<0.05)$, volatile solids $(p<0.05)$, total Kjeldahl nitrogen $(p<0.05)$ and total organic carbon $(p<0.05)$. The lowest TS and VS characterized CS and were equal to $2.97 \pm 0.06 \%$ and $42.02 \pm 0.59 \% \mathrm{TS}$, respectively. The CS also showed the highest TKN content $\left(107.3 \pm 0.7 \mathrm{~g} \cdot \mathrm{kg}^{-1} \mathrm{dm}\right)$ and the lowest TOC content $\left(252.1 \pm 18.5 \mathrm{~g} \cdot \mathrm{kg}^{-1} \mathrm{dm}\right)$, which was reflected in very low $\mathrm{C} / \mathrm{N}$ ratio equal to 2 . Cattle slurry had the lowest content of total $\mathrm{P}$ and the highest content of total $\mathrm{K}$ (Table 1). In contrast, the chemical composition of both digestates was similar, which was a result of using the digestate from biogas plant as an inoculum in the biomethane potential test performed on common reed silage.

Table 1

Selected chemical characteristics of organic materials used for incubation (mean value \pm standard deviation, data expressed on a dry matter basis)

\begin{tabular}{|c|c|c|c|}
\hline Parameter & $\begin{array}{c}\text { Common reed } \\
\text { digestate (CRD) }\end{array}$ & $\begin{array}{c}\text { Cattle } \\
\text { slurry (CS) }\end{array}$ & $\begin{array}{c}\text { Digestate } \\
\text { (MSD) }\end{array}$ \\
\hline Total solids (TS), \% & $6.28 \pm 0.11$ & $2.97 \pm 0.06$ & $7.21 \pm 0.13$ \\
\hline Volatile soilids (VS), \% TS & $71.10 \pm 0.11$ & $42.02 \pm 0.59$ & $72.59 \pm 0.28$ \\
\hline Total Kjeldahl nitrogen (TKN), $\mathrm{g} \cdot \mathrm{kg}^{-1}$ & $46.8 \pm 5.6$ & $107.3 \pm 0.7$ & $61.5 \pm 3.1$ \\
\hline Total organic carbon (TOC), $\mathrm{g} \cdot \mathrm{kg}^{-1}$ & $353.0 \pm 8.3$ & $252.1 \pm 18.5$ & $389.5 \pm 12.1$ \\
\hline Total phosphorus (TP), $\mathrm{g} \cdot \mathrm{kg}^{-1}$ & $9.4 \pm 0.4$ & $1.0 \pm 0.1$ & $11.8 \pm 0.3$ \\
\hline Total potassium (TK), $\mathrm{g} \cdot \mathrm{kg}^{-1}$ & $61.4 \pm 0.8$ & $232.7 \pm 8.4$ & $50.0 \pm 1.2$ \\
\hline
\end{tabular}

The addition of fertilizers to the soil resulted in an increase of the $\mathrm{NH}_{4}-\mathrm{N}$ concentration in the treated soils comparing to control. The highest amount of ammonium was observed in the soil treated with cattle slurry $\left(85.17 \pm 10.13 \mathrm{mg} \mathrm{N} \cdot \mathrm{kg}^{-1}\right)$, while the initial $\mathrm{NH}_{4}-\mathrm{N}$ content in control was equal to $14.86 \pm 0.60 \mathrm{mg} \mathrm{N} \cdot \mathrm{kg}^{-1}$. During the first two weeks of incubation the $\mathrm{NH}_{4}-\mathrm{N}$ content decreased rapidly in all treated soils and accounted for $16.25 \pm 12.02,19.02 \pm 4.12$ and $40.20 \pm 1.83 \mathrm{mg} \mathrm{N} \cdot \mathrm{kg}^{-1}$ soil fertilized with CRD, MSD and CS, respectively. Addition of organic fertilizers with a high content of $\mathrm{N}$ in form of ammonium to the soil increased the $\mathrm{NH}_{4}-\mathrm{N}$ content in soil immediately, what indicated that most of the nitrogen in all fertilizers was in form of ammonium [10]. The addition of fertilizers triggers the nitrification processes [13] and the rapid decrease in soil of the $\mathrm{NH}_{4}-\mathrm{N}$ content is the consequence of this process, because mixing the amendments with soil prevents $\mathrm{N}$ losses through ammonia volatilization [14]. On the next days of incubation, the $\mathrm{NH}_{4}-\mathrm{N}$ dynamics in soils fertilized with CRD and MSD followed a similar pattern. The ammonium content was stable for two weeks, whereby dropped down to almost zero on day 42 (Fig. 1). In the soil treated with CS the decline of the $\mathrm{NH}_{4}-\mathrm{N}$ content was constant from $40.20 \pm 1.83 \mathrm{mg} \mathrm{N} \cdot \mathrm{kg}^{-1}$ on day 14 to the value close to zero on day 42.

The $\mathrm{NO}_{3}-\mathrm{N}$ content in all soils ranged between $4.00 \pm 0.47$ and $6.35 \pm 0.35 \mathrm{mg} \mathrm{N} \cdot \mathrm{kg}^{-1}$ at the beginning of the experiment (day 0 ). The nitrification in control was rather slow and the $\mathrm{NO}_{3}-\mathrm{N}$ content reached its maximum equal to $42.65 \pm 3.01 \mathrm{mg} \mathrm{N} \cdot \mathrm{kg}^{-1}$ on day 28 and after that day it was fairly constant until the end of incubation (day 56). The most rapid increase in the $\mathrm{NO}_{3}-\mathrm{N}$ content was observed in the soil treated with CS, from $4.00 \pm 0.47 \mathrm{mg} \mathrm{N} \cdot \mathrm{kg}^{-1}$ on day 0 to $94.83 \pm 8.17 \mathrm{mg} \mathrm{N} \cdot \mathrm{kg}^{-1}$ on day 28. The nitrification in soils amended with CRD followed a similar pattern, the $\mathrm{NO}_{3}-\mathrm{N}$ content increased from $5.62 \pm 0.84 \mathrm{mg} \mathrm{N} \cdot \mathrm{kg}^{-1}$ on day 0 to $76.43 \pm 43 \mathrm{mg} \mathrm{N} \cdot \mathrm{kg}^{-1}$ on day 28 and was rather stable until the end of the experiment. Slower nitrification was observed in the soil treated with MSD, 
in which the $\mathrm{NO}_{3}-\mathrm{N}$ content rose from $6.35 \pm 0.35 \mathrm{mg} \mathrm{N} \cdot \mathrm{kg}^{-1}$ on day 0 to $79.06 \pm 13.95 \mathrm{mg} \mathrm{N} \cdot \mathrm{kg}^{-1}$ on day 42 (Fig. 1). Slower release of $\mathrm{NO}_{3}-\mathrm{N}$ in soils amended with MSD may be the advantage of digestate use as fertilizer comparing to cattle slurry, because in the case of soils fertilized with digestate the plants are able to uptake the nitrates more efficiently and, in consequence, this may prevent or at least decrease $\mathrm{N}$ leaching. However, other investigations revealed very rapid nitrification, which may be a limiting factor in digestate application to soils [15]. This pattern was observed for CSG digestate and was parallel to the N-dynamics in the soils treated with CS.

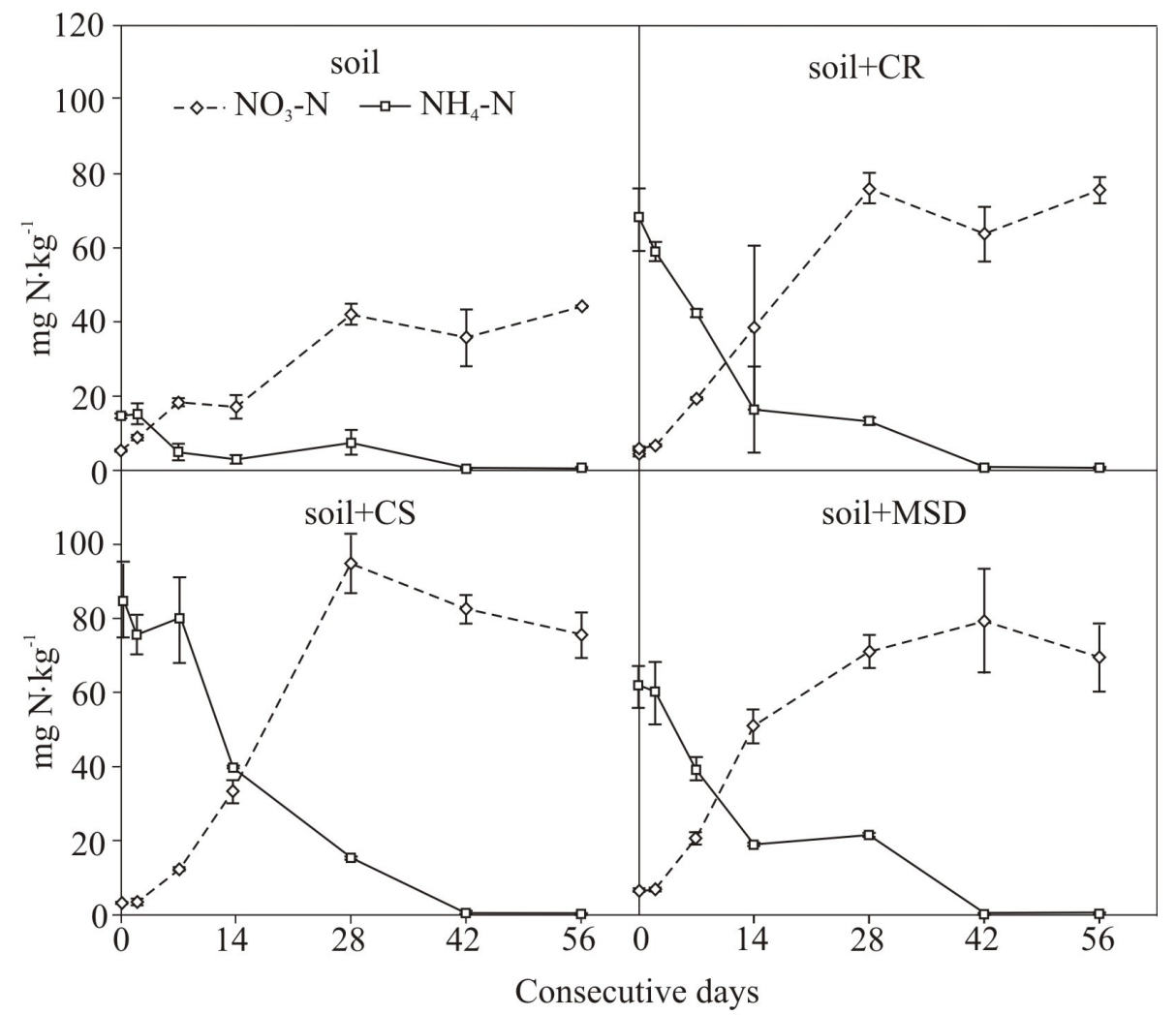

Fig. 1. $\mathrm{NO}_{3}-\mathrm{N}$ and $\mathbf{N H}_{4}-\mathrm{N}$ evolution during incubation experiment (mean value \pm standard deviation, where absent, bars fall within symbols) in control soil (soil), and treated soils with common reed digestate (CRD), cattle slurry (CS) and with digestate from maize silage codigested with chicken droppings and potato pulp (MSD)
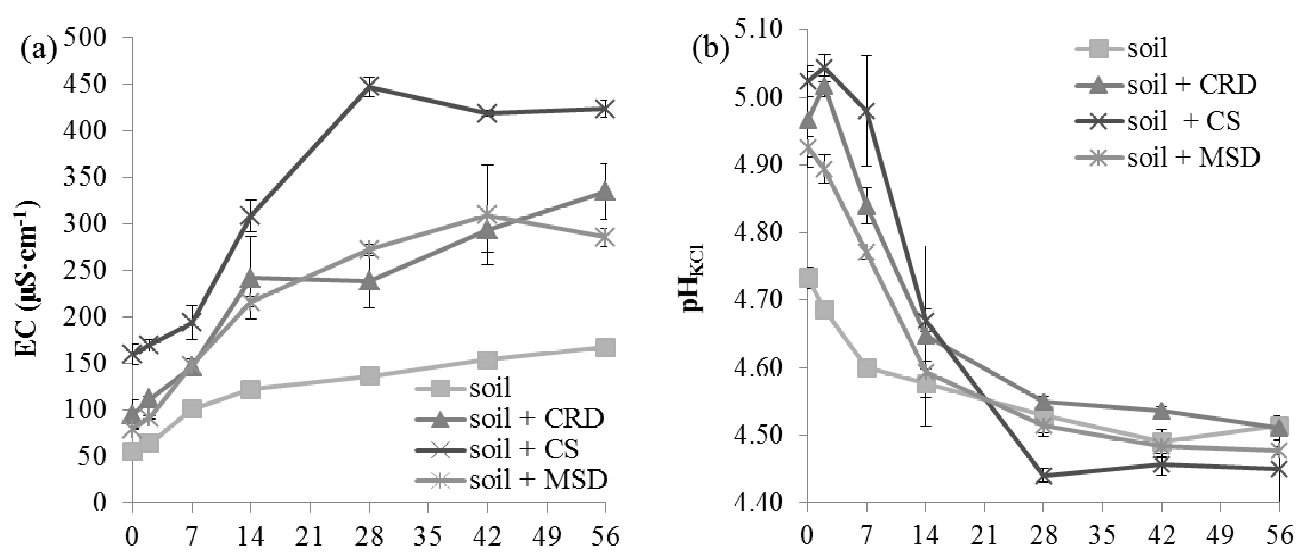

Fig. 2. Soil $\mathbf{E C}$ (a) and $\mathbf{p H}_{\mathrm{KCl}}$ (b) evolution during incubation experiment (mean value \pm standard deviation, where absent, bars fall within symbols) in control soil (soil), and treated soils with common reed digestate (CRD), cattle slurry (CS) and with digestate from maize silage codigested with chicken droppings and potato pulp (MSD) 
The electrical conductivity in all amended soils was higher than in control. The EC was influenced by the type of amendment and the highest EC values, rising from $159.8 \mu \mathrm{S} \cdot \mathrm{cm}^{-1}$ on day 0 to $423.3 \mu \mathrm{S} \cdot \mathrm{cm}^{-1}$ on day 56 (Fig. 2a), were observed throughout the whole incubation for CS and were significantly higher $(\mathrm{p}<0.05)$ than in control. These values and the overall EC dynamics are in a good agreement with the results obtained by [13]; however, in our study, the EC value at the end of incubation was higher than this given by [13]. The EC was very similar for both soils treated with digestates and ranged from 95.3 to $335.0 \mu \mathrm{S} \cdot \mathrm{cm}^{-1}$ and from 80.1 to $309.3 \mu \mathrm{S} \cdot \mathrm{cm}^{-1}$ for CRD and MSD, respectively. This similarity is a result of the origin of CRD digestate, which is the product of anaerobic digestion of common reed silage with maize silage digestate used as inoculum in the biomethane potential test. The EC pattern in all treated soils and in control followed the dynamics of $\mathrm{NO}_{3}-\mathrm{N}$ with the highest peaks on the same days as maximum $\mathrm{NO}_{3}-\mathrm{N}$ content, except for CRD. In all treated soils the EC values are much lower than the threshold level of $2000 \mu \mathrm{S} \cdot \mathrm{cm}^{-1}$ for salinity. The $\mathrm{pH}_{\mathrm{KCl}}$ of the treated soils ( $\left.\sim 5.0\right)$ was higher than control (4.7) at the beginning of the experiment (day 0 ) and decreased to a similar value of $\sim 4.5$ in all studied soils and in control at the end of the experiment (Fig. 2b). The $\mathrm{pH}$ decline in the first two weeks after application of raw manure and digestates is similar to the $\mathrm{pH}$ pattern in soil fertilized with raw and digested pig slurry [10]. This rapid decrease in $\mathrm{pH}$ suggests that digestate like cattle slurry should be added to acidic soils with cautions, following the good agricultural practices code.

All organic materials used in this study supply the soil in high amounts of nitrogen in plantavailable form. The cattle slurry addition resulted in the highest $\mathrm{NH}_{4}-\mathrm{N}$ content in the soil. However, when the nitrogen content in organic fertilizers is recalculated to the fresh weight, its content in CS (3.43 $\left.\mathrm{g} \mathrm{N} \cdot \mathrm{kg}^{-1} \mathrm{ww}\right)$ is lower than in MSD (4.44 $\left.\mathrm{g} \mathrm{N} \cdot \mathrm{kg}^{-1} \mathrm{ww}\right)$, therefore, to achieve similar $\mathrm{N}$ dosage the fertilization with CS demands more fuel. Low N content in CS fresh material, rapid nitrification with the lowest $\mathrm{P}$ content lower the value of this organic fertilizer. On the other hand, digestate produced from energy crops like maize demands more fuel and mineral fertilizers during the growing stage. It is worth noting that mineral fertilizers can be replaced by digestate in this cycle; however, the fuel and land demand still are the disadvantages in case of this organic fertilizer. The solution may be at least partial substitution of maize with common reed silage in biogas production. This may result in the production of more eco-friendly energy together with valuable fertilizer.

\section{Conclusions}

Although the organic materials used in this study had differed significantly in chemical properties (eg., TKN content equals to $46.8 \pm 5.6 \mathrm{mg} \cdot \mathrm{kg}^{-1}, 61.5 \pm 3.1 \mathrm{mg} \cdot \mathrm{kg}^{-1}$ and $107.3 \pm 0.76 \mathrm{mg} \cdot \mathrm{kg}^{-1}$ for CRD, MSD and CS, respectively), they all had supplied the soil with high amounts of plant-available nitrogen, which resulted in much higher $\mathrm{NH}_{4}-\mathrm{N}$ content in the treated soil (from $61.5 \pm 5.67 \mathrm{mg} \mathrm{N} \cdot \mathrm{kg}^{-1}$ to $\left.85.17 \pm 10.13 \mathrm{mg} \mathrm{N} \cdot \mathrm{kg}^{-1}\right)$ comparing to the unamended soil $\left(14.84 \pm 0.60 \mathrm{mg} \mathrm{N} \cdot \mathrm{kg}^{-1}\right)$. Addition of different organic fertilizers to the soil triggered a range of processes including nitrification, immobilization, and emission; however, the most pronounced process was nitrification of the applied $\mathrm{NH}_{4}-\mathrm{N}$, which content in the soil decreased to values close to zero, while the $\mathrm{NO}_{3}-\mathrm{N}$ content increased to $76.43 \pm 43 \mathrm{mg} \mathrm{N} \cdot \mathrm{kg}^{-1}, 79.06 \pm 13.95 \mathrm{mg} \mathrm{N} \cdot \mathrm{kg}^{-1}$ and $94.83 \pm 8.17 \mathrm{mg} \mathrm{N} \cdot \mathrm{kg}^{-1}$ in the soils treated with CRD, MSD and CS, respectively. The pattern of inorganic-N transformation suggests that digestate from common reed silage can be used successfully as organic fertilizer but fast nitrification may lead to enhanced loss of $\mathrm{NO}_{3}-\mathrm{N}$ by leaching. Therefore, application of digestate should follow the same rules as traditional liquid organic fertilizers.

\section{Acknowledgements}

This work was financially supported by the Ministry of Science and Higher Education as a part of the project $\mathrm{S} / \mathrm{WBiIŚ} / 01 / 17$.

\section{References}

[1] Rigby H. Smith S.R. Nitrogen availability and indirect measurements of greenhouse gas emissions from aerobic and anaerobic biowaste digestates applied to agricultural soils. Waste Management, vol. 33, 2013, pp. 2641-2652. 
[2] Insam H., Gómez-Brandón M., Ascher J. Manure-based biogas fermentation residues - Friend or foe of soil fertility? Soil Biology \& Biochemistry vol. 84, 2015, pp.1-14.

[3] Pivato A., Vanin S., Raga R. etc. Use of digestate from decentralized on-farm biogas plants as fertilizer in soil: An ecotoxicological study for future indicators in risk and life cycle assessment. Waste Management, vol. 49, 2016, pp. 378-389.

[4] Banaszuk H., Wysocka-Czubaszek A., Czubaszek R., Roj-Rojewski S. Skutki energetycznego wykorzystania biomasy (Implications of biomass use for energy production). Village and Agriculture: Wieś i rolnictwo, Vol. 4(169), 2015, pp. 139-152. (In Polish)

[5] Blokhina Y.N., Prochnow A., Plöchl M., Luckhaus C., Heiermann M. Concepts and profitability of biogas production from landscape management grass. Bioresource Technology, vol. 102, 2011, pp. 2086-2092.

[6] Roj-Rojewski S. Wysocka-Czubaszek A., Czubaszek R., Banaszuk P. Does wetland biomass provide an alternative to maize in biogas generation? In: K. Mudryk and S. Werle (eds.), Renewable Energy Sources: Engineering Technology, Innovation, Springer Proceedings in Energy, https://doi.org/10.1007/978-3-319-72371-6_13

[7] Golkowska K., Rugani B., Koster D., Van Oers C. Environmental and economic assessment of biomass sourcing from extensively cultivated buffer strips along water bodies. Environmental Science \& Policy, vol. 57, 2016, pp. 31-39.

[8] Banaszuk P., Kamocki K.K., Zarzecki R. Mowing with invasive machinery can affect chemistry and trophic state of rheophilous mire. Ecological Engineering, vol. 86, 2016, pp. 31-38.

[9] Alburquerque J.A., de la Fuente C., Bernal M.P. Chemical properties of anaerobic digestates affecting $\mathrm{C}$ and $\mathrm{N}$ dynamics in amended soils. Agriculture, Ecosystems \& Environment, vol. 160, 2012, pp. 15-22.

[10] Loria E.R., Sawyer J.E. Extractable soil phosphorus and inorganic nitrogen following application of raw and anaerobically digested swine manure. Agronomy Journal, vol. 97, 2005, pp. 879-885.

[11] Journal of Laws of 2007 No. 147 item 1033. Act of 10 July 2007 on fertilizers and fertilizing.

[12] American Public Health Association. Standard methods for the examination of water and waste water, Twentieth edition. Washington, DC, USA, 1999, $1268 \mathrm{p}$.

[13] Gómez-Brandón M., Juárez M.F.-D., Zangerle M., Insam H. Effects of digestate on soil chemical and microbiological properties: A comparative study with compost and vermicompost. Journal of Hazardous Materials, vol. 302, 2016, pp. 267-274.

[14] de la Fuente C., Clemente R., Martínez J., Bernal, M.P. Optimisation of pig slurry application to heavy metal polluted soils monitoring nitrification processes. Chemosphere, vol. 81, 2010, pp. 603-610.

[15] Grigatti M., Di Girolamo G., Chincarini R. etc. Potential nitrogen mineralization, plant utilization efficiency and soil $\mathrm{CO} 2$ emissions following the addition of anaerobic digested slurries. Biomass \& Bioenergy, vol. 35, 2011, pp. 4619-4629. 